Дитяча стоматологія

УДК 616.31-083-053.4

DOI 10.11603/2311-9624.2020.4.11723

СО. І. Годованець, А. В. Котельбан, П. В. Мороз

Буковинський державний медичний університет, м. Чернівці

e-mail: kotelban_anastasiia@bsmu.edu.ua

\title{
Оцінка стану стоматологічного здоров'я та якості життя дітей-дошкільнят за результатами анкетування батьків
}

ІНФОРМАЦІЯ

Надійшла до редакції/Received: 26.11.2020 p.

Ключові слова: стоматологічне здоров'я; карієс; EGOHID.

\section{АНОТАЦІЯ}

Резюме. Карієс тимчасових зубів є важливою соціальною проблемою дитячого віку в усіх країнах світу, адже поширеність цього захворювання коливається від 25 до 72 \%. Вважається, що основною причиною руйнування зубів є результат життєдіяльності карієсогенних мікроорганізмів за умови високої насиченості вуглеводами та зниженої карієсорезистентності зубів. Неповноцінна гігієна ротової порожнини, несприятливі умови для самоочищення зубів, надмірне споживання солодощів, недостатнє надходження фторидів є одними з найвагоміших чинників ризику розвитку карієсу. Мета дослідження - оцінити ставлення батьків дітей 3-х та 6-ти років до стоматологічного здоров'я та якості життя дітей за модифікованими критеріями EGOHID.

Матеріали і методи. Із цією метою за допомогою Google-форми проведено опитування 257 батьків дітей віком 3 та 6 років (122 хлопців та 135 дівчат). Суб'єктивна оцінка стоматологічного здоров’я включала запитання щодо частоти чищення зубів, оцінки стану зубів та ясен, засобів та предметів догляду за ротовою порожниною та перевірки ефективності чищення зубів, особливостей харчування, перш за все вживання солодощів, а також назагал чи батьки звертають увагу на вигляд молочних зубів у дітей, кратність відвідування лікарів загального профілю, у тому числі й стоматолога. Результати досліджень та іх обговорення. Ми встановили, що більше половини (57,26 \%) батьків вперше звертаються до стоматолога задля лікування їхніх дітей, а для профілактичного огляду - тільки 25,67 \%. Догляд за ротовою порожниною з появою першого зуба розпочали 56,62 \% батьків, після року - 37,43 \% опитаних, із двох років - 16,05 \%. Тільки половина респондентів (49,36 \%) чистить зуби дітям двічі на день, решта - лише 1 раз. Тішить, що більшість батьків $(67,67$ \%) все-таки чистять зуби своїм дітям самі, однак ефективність чищення зубів перевіряють спеціальним розчином тільки 3,22 \% опитаних. Щодо складу зубної пасти, то лише 47,93 \% батьків дітей вказують на використання кальційумісної зубної пасти, решту не знають склад пасти. Допоміжних засобів для чищення зубів 99,14 \% опитаних батьків не використовують. 55,52 \% респондентів вказують на споживання дітьми солодощів 1 раз на день, третя частина (відповідно 30,84 \%) - декілька разів на день, решту - рідше. 46,23 \% опитаних вважають, що звертатися до лікарів-стоматологів потрібно тільки в разі гострого болю. На потребу в лікуванні молочних зубів вказали 65,76 \% батьків, решту вважають це необов'язковим. На вибір засобів та предметів гігієни ротової порожнини найчастіше впливає телебачення $(41,89 \%)$ та навколишні люди (у 32,45 \%).

Висновки. У результаті суб'єктивного опитування ми встановили недостатню увагу батьків до стану здоров'я зубів дітей, неповноцінний догляд за ротовою порожниною та недоліки в харчуванні. 
Вступ. Карієс тимчасових зубів є важливою соціальною проблемою дитячого віку в усіх країнах світу, адже поширеність цього захворювання коливається від 25 до 72 \% [1-6]. Вважається, що основною причиною руйнування зубів є результат життєдіяльності карієсогенних мікроорганізмів за умови високої насиченості вуглеводами та зниженої карієсорезистентності зубів. Неповноцінна гігієна ротової порожнини, несприятливі умови для самоочищення зубів, надмірне споживання солодощів, недостатнє надходження фторидів $€$ одними з найвагоміших чинників ризику розвитку карієсу [1-4].

Недавній огляд SIGN показав, що неуважне ставлення батьків до гігієни ротової порожнини дитини є індикатором ризику розвитку в неї карієсу з рівнем доказовості 3. При цьому такі чинники ризику, як наявність у матері каріозних зубів, високого рівня Streptococcus mutans i надмірне вживання цукрів не впливали на розвиток карієсу в дитини (рівень доказовості 2+) [2].

Батьки є ключовою ланкою в розвитку та підтримці стоматологічного здоров'я дітей. Їхнє здоров'я ротової порожнини, знання 3 питань профілактики стоматологічних захворювань та ставлення до гігієни ротової порожнини назагал роблять значний вплив на стан стоматологічного здоров'я дитини [1-4, 5]. Саме тому медична, і перш за все стоматологічна, грамотність батьків є пріоритетним напрямком задля досягнення належного рівня профілактики стоматологічних захворювань у дітей.

Метою дослідження було оцінити ставлення батьків дітей 3 та 6 років до стоматологічного здоров'я та якості життя їхніх дітей за критеріями EGOHID.

Матеріали і методи. Із цією метою проведено за допомогою Google-форми опитування 257 батьків дітей віком 3 та 6 років. Для оцінки поінформованості батьків 3 основами гігієни ротової порожнини та догляду за зубами ми розробили анкету із запитаннями (індикаторами) 3 декількома варіантами відповідей. Суб'єктивна оцінка стоматологічного здоров'я включала запитання щодо терміну першого візиту дитини до стоматолога; віку, з якого дитина почала чистити зуби та хто навчив дитину доглядати за зубами; частоти чищення зубів, оцінки стану зубів та ясен, засобів та предметів для чищення зубів та перевірки ефективності чищення зубів, особливостей харчування, перш за все споживання солодощів, а також назагал чи батьки звертають увагу на вигляд молочних зубів у дітей, кратність відвідування лікарів загального профілю, у тому числі й стоматолога.

Результати досліджень та їх обговорення. На нашу думку, стан молочних зубів дітей відображає рівень гігієнічних навичок та надання стоматологічної допомоги, що безсумнівно має величезний вплив на ріст та розвиток зубощелепної системи, а також назагал на здоров'я ротової порожнини. А рівень стоматологічної санітарної освіти дітей, перш за все дошкільного віку, є відображенням знань та вмінь їхніх батьків.

Розуміння поняття «перший візит до стоматолога» якраз і перший тому доказ. Відповіді на запитання «3 якою метою батьки звернулися до стоматолога вперше» були різними: задля профілактичного огляду - 25,67 \% опитаних батьків дітей. Більше половини (57, 26 \%) опитаних батьків вказали, що відвідували стоматолога для лікування їхніх дітей, а 15,38 $\%$ дітей ще навіть не зверталися на перший прийом.

Щодо віку дітей при першому візиті, то більшість (65,35 \%) батьків вказала на відвідування дітьми стоматолога вже після 3 років (рис. 1). Такі результати відображають високі показники поширеності карієсу тимчасових зубів. Адже своєчасні й регулярні огляди ротової порожнини (не рідше раз на півроку, починаючи 31 року) сприяють ранній клінічній діагностиці карієсу та вчасному правильному плануванню лікувальних і профілактичних заходів.

Догляд за ротовою порожниною 3 появою першого зуба розпочали 56,62 \% батьків, після року - 37,43 \% опитаних, із двох років - 16,05 \%. Низька обізнаність батьків щодо початку догляду за зубами малюків вказує на недостатню санітарну стоматологічну роботу самими лікарями-стоматологами, а також і лікарямипедіатрами.

Половина респондентів (49,36 \%) чистить зуби дітям двічі на день, 21,78 \% батьків чистять зуби дітям лиш ввечері, а 19,52 \% - лиш зранку. 9,34 \% батьків нерегулярно чистять зуби дітям (рис. 2). Це свідчить про те, що батьки не завжди уважно ставляться до гігієни зубів дітей.

Щодо відповіді на запитання «Хто чистить зуби дитині?», то третина опитаних довіряє 


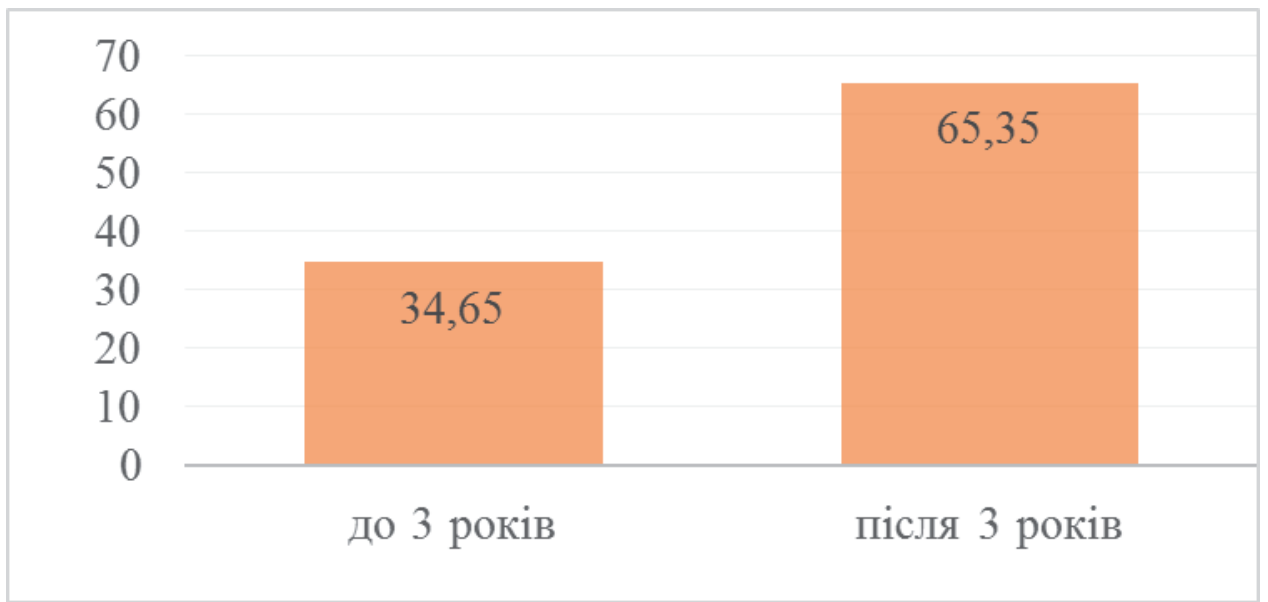

Puc. 1. Результати анкетування «В якому віці дитина вперше відвідала стоматолога?».

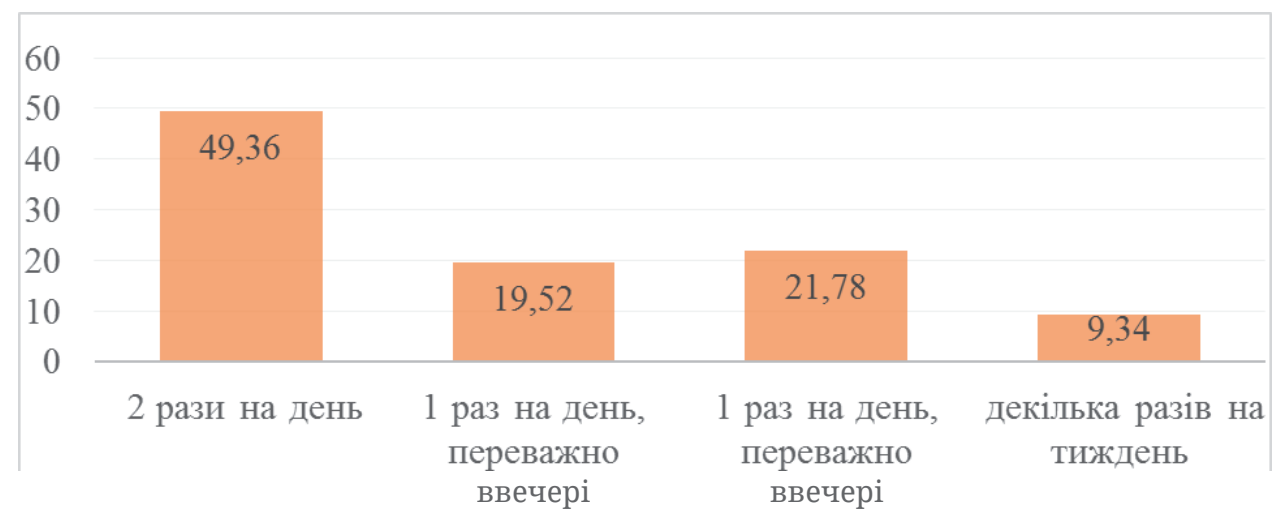

Puc. 2. Результати анкетування «Як часто чистять зуби Ваші діти?».

процес чищення зубів самим дітям. Тішить, що більшість батьків $(67,67 \%)$ все-таки чистить зуби своїм дітям. До 5-6 років гігієну ротової порожнини дитини забезпечують батьки, 3 5-6 років дитина виконує основну чистку зубів щіткою самостійно. Батьки контролюють якість чищення і поступово навчають дитину цій процедурі [8].

Цікавим $€$ те, що ефективність чищення зубів перевіряють спеціальним розчином тільки $3,22 \%$ опитаних, решту - не перевірять.
Ми встановили, що 12,45 \% батьків звертають увагу на зуби дітей кілька разів на день, $35,22 \%$ батьків дивляться на зуби кілька разів на тиждень та 27,14 \% - декілька разів на тиждень. Щонайменше раз на день заглядають до ротової порожнини дітей 25,19 \% респондентів. Отримані результати власне і суперечать результатам чищення двічі на день (рис. 3).

Майже всі діти (99,16 \%) чистять зуби зубною щіткою та зубною пастою, лише батьки

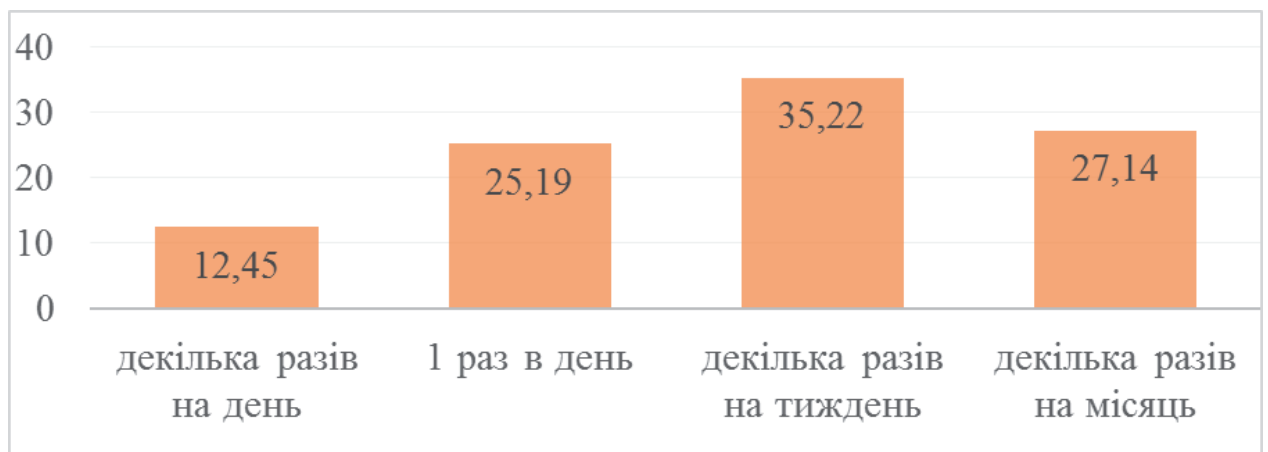

Puc. 3. Результати анкетування «Як часто Ви звертаєте увагу на вигляд зубів Ваших дітей?». 
1 дитини вказують на використання зубного порошку.

Що стосується використання власне зубної пасти, то лише 47,93 \% батьків дітей вказують на використання зубної пасти, що містить кальцій, решту не знають склад пасти. 3і слів батьків, фторумісну зубну пасту діти не використовують. Ми вважаємо, що такі результати вказують на низький рівень санітарної стоматологічної освіти батьків та байдужість самих батьків до здоров'я дітей. Недостатнє надходження сполук фтору в організм дитини є основним фактором розвитку карієсу зубів. Провідні світові стоматологічні та педіатричні асоціації рекомендують ранне використання домашніх фторумісних паст. При дворазовому застосуванні на день пасти з низькою концентрацією фториду (500 ppm) можливе надходження фториду в організм дітей не перевищує добового фторнавантаження за умови використання «мазка" для дітей до 2 років і горошини для дітей від 2 до 6 років [8].
Щодо допоміжних засобів для чищення зубів, то 99,14 \% опитаних батьків їх не використовують. Якщо вибирають, то жуйку (відповідно $2,11 \%$ ч) чи зубну нитку (3,75 \%). Із 5-6 років батьки повинні контролювати якість чищення і проводити флосинг, поступово навчаючи дитину цій процедурі [8].

Щодо солодощів, то 55,52 \% батьків дітей вказують на споживання дітьми солодощів 1 раз на день, третя частина опитаних (відповідно 30,84 \%) - декілька разів на день, решта - рідше (рис. 4).

Думки щодо потреби у відвідуванні стоматолога розділилися: 46,23 \% опитаних вважають, що звертатися до лікарів-стоматологів потрібно тільки в разі гострого болю, 44,32 \% - 1 раз на рік і тільки 9,45 \% - двічі на рік (рис. 5).

На потребу в лікуванні молочних зубів вказали 65,76 \% батьків, решта - що це необов'язкова процедура. Уточнюючи останнє, чверть батьків $(25,54 \%)$ лікує молочні зуби тільки у разі болю.

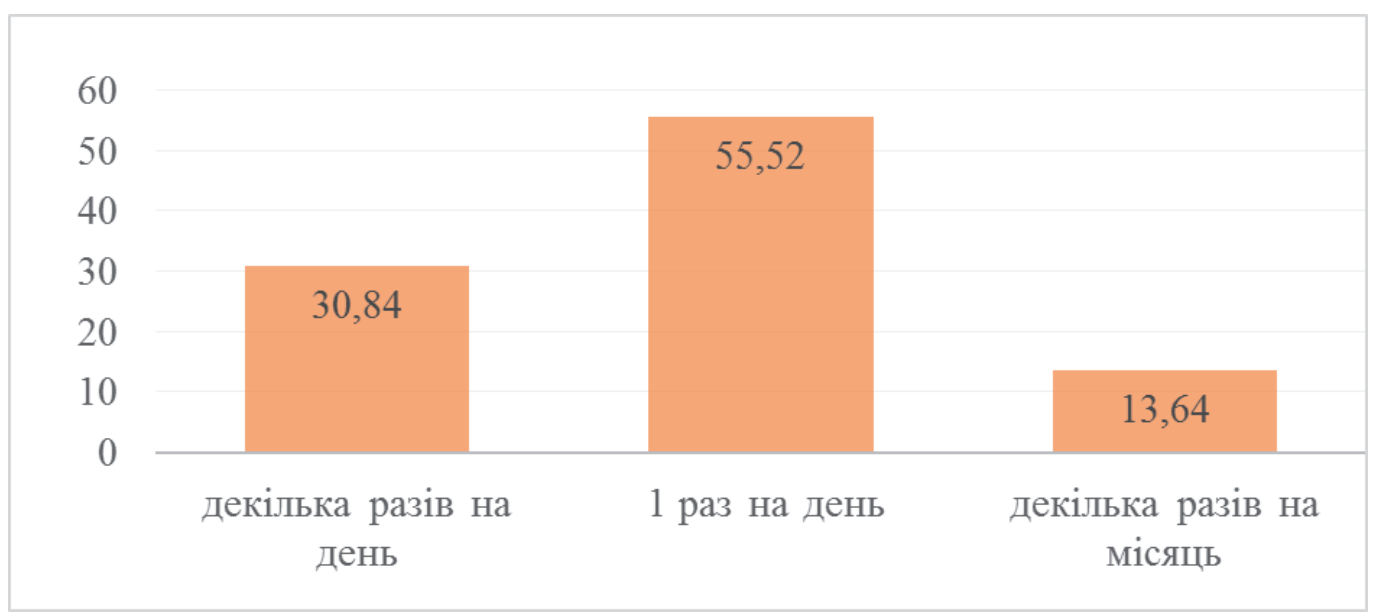

Puc. 4. Результати анкетування «Як часто Ваші діти вживають солодощі, навіть у малих кількостях?».

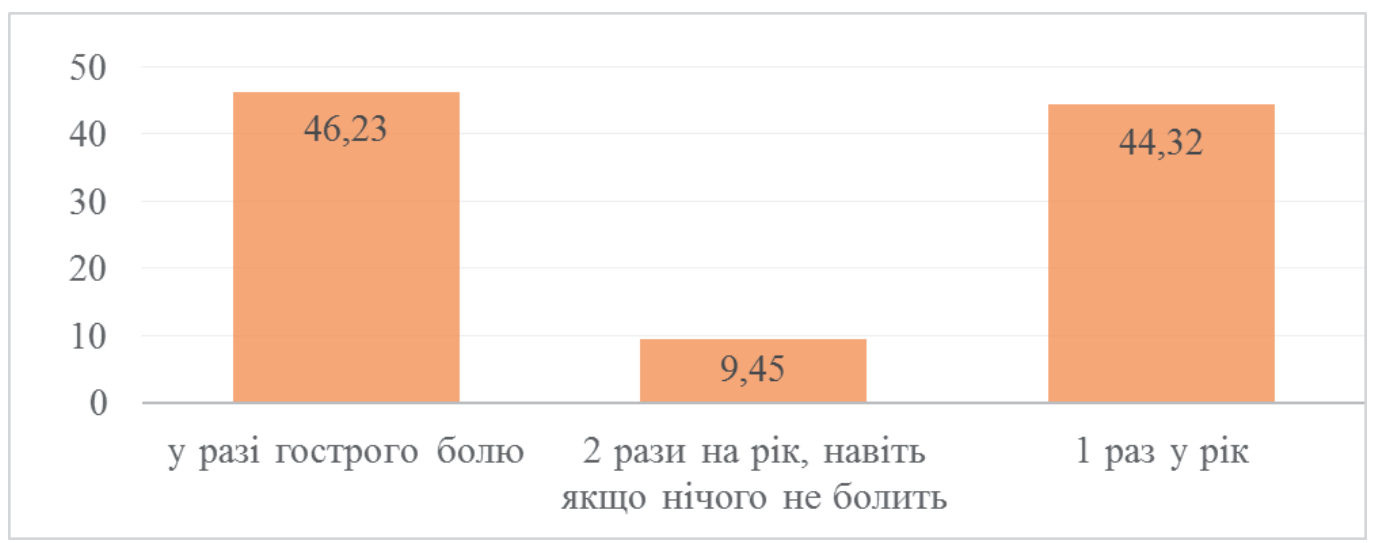

Puc. 5. Результати анкетування «Як часто, на Вашу думку, потрібно відвідувати дітям стоматолога?». 
На вибір батьків щодо засобів та предметів гігієни ротової порожнини найчастіше впливає телебачення (41,89 \%) та навколишні люди (у 32,45 \%). Порад лікаря-стоматолога дотримується тільки четверта частина опитаних (25,66 \%) (рис. 6).

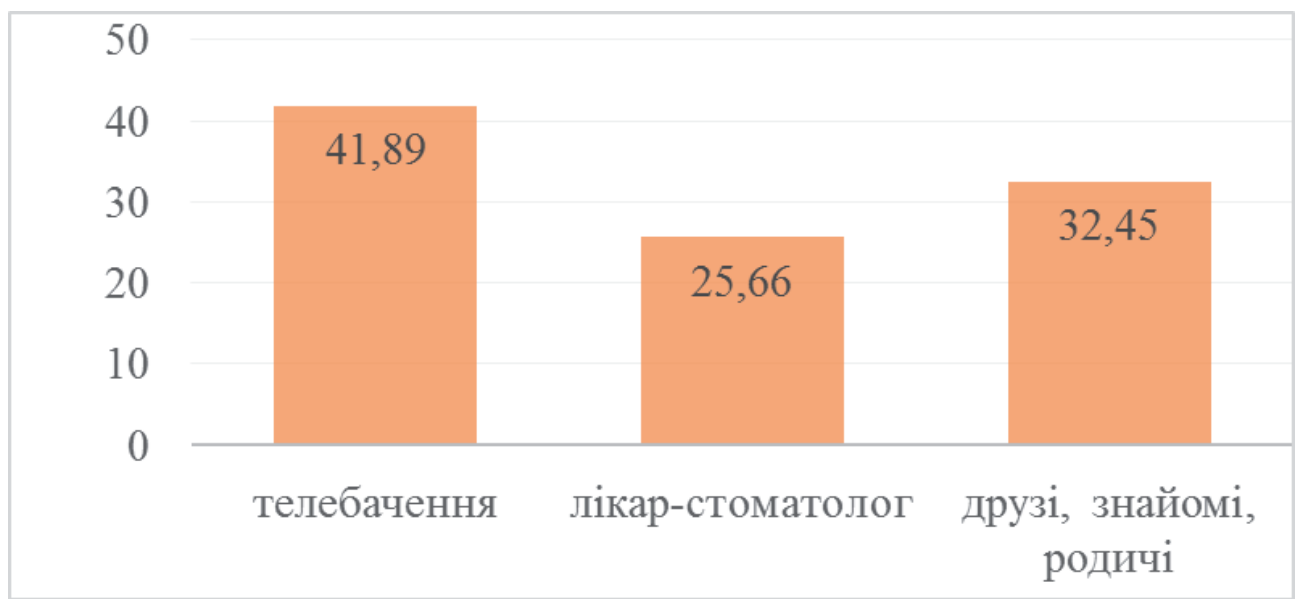

Puc. 6. Результати анкетування «Хто впливає на вибір Вами засобів та предметів гігієни ротової порожнини для дітей?».

Висновки. Суб’єктивні дані опитування вказують на недостатню увагу батьків до стану здоров'я зубів дітей, неповноцінний догляд за ротовою порожниною та недоліки в харчуванні.

\section{(с) И. И. Годованец, А. В. Котельбан, П. В. Мороз}

Буковинский государственный медицинский университет, г. Черновцы

\section{Оценка состояния стоматологического здоровья и качества жизни детей-дошкольников по результатам анкетирования родителей}

Резюме. Кариес временных зубов является важной социальной проблемой детского возраста во всех странах мира, ведь распространенность этого заболевания колеблется от 25 до 72 \%. Считается, что основной причиной разрушения зубов есть результат жизнедеятельности кариесогенных микроорганизмов при высокой насыщенности углеводами и пониженной кариесрезистентности зубов. Неполноценная гигиена ротовой полости, неблагоприятные условия для самоочищения зубов, чрезмерное потребление сладостей, недостаточное поступление фторидов являются одними из наиболее значимых факторов риска развития кариеса.

Цель исследования - оценить отношение родителей детей 3-х и 6-ти лет до стоматологического здоровья и качества жизни детей с модифицированными критериями EGOHID.

Материалы и методы. С этой целью с помощью Google-формы проведено опрос 257 родителей детей 3 и 6 лет (122 мальчиков и 135 девочек). Субъективная оценка стоматологического здоровья включала вопрос о частоте чистки зубов, оценки состояния зубов и десен, средств и предметов ухода за полостью рта и проверки эффективности чистки зубов, особенностей питания, прежде всего употребление сладостей, а также в целом или родители обращают внимание на вид молочных зубов у детей, кратность посещения врачей общего профиля, в том числе и стоматолога.

Результаты исследований и их обсуждение. Нами установлено, что более половины $(57,26$ \%) родителей впервые обращаются к стоматологу для лечения их детей, а для профилактического осмотра - только 25,67 \%. Уход за полостью рта с появлением первого зуба начали 56,62 \% родителей, после года - 37,43 \% опрошенных, с двух лет - 16,05 \%. Только половина респондентов (49,36 \%) чистит зубы детям дважды в день, остальные - лишь 1 раз. Радует, что большинство родителей $(67,67 \%)$ все же чистят зубы своим детям сами, однако эффективность чистки зубов проверяют специальным раствором только 3,22 \% опрошенных. По составу зубной пасты, то только 47,93 \% родителей детей указывают на использование кальцийвместимой зубной пасты, остальные не знают состав пасты. Вспомогательных средств для чистки зубов 99,14 \% опрошенных родителей не используют. 55,52 \% респондентов указывают на употребление детьми сладостей 1 раз в день, третья часть (соответствен- 
но 30,84 \%) - несколько раз в день, остальное - реже. 46,23 \% опрошенных считают, что обращаться к врачам-стоматологам нужно только в случае острой боли. На потребность в лечении молочных зубов указали 65,76 \% родителей, остальные считают это необязательным. На выбор средств и предметов гигиены полости рта чаще всего влияет телевидение (41,89 \%) и окружающую круг людей (в 32,45 \%). Выводы. В результате субъективного опроса нами установлено недостаточное внимание родителей к состоянию здоровья зубов детей, неполноценный уход за полостью рта и недостатки в питании.

Ключевые слова: стоматологическое здоровье; кариес; EGOHID.

\author{
CO. I. Godovanets, A. V. Kotelban, P. V. Moroz
}

Bukovynian State Medical University

\title{
Assessment of the state of dental health and quality of life of preschool children according to the results of the parents' questionnaires
}

Summary. Caries of temporary teeth is an important social problem of childhood in all countries of the world, because the prevalence of this disease ranges from 25 to $72 \%$. It is believed that the main cause of tooth decay is the result of the activity of cariogenic microorganisms under conditions of high carbohydrate saturation and reduced caries resistance of teeth. Poor oral hygiene, unfavorable conditions for self-cleaning teeth, excessive consumption of sweets, insufficient intake of fluoride are among the most important risk factors for caries.

The aim of the study - to assess the attitude of parents of children aged 3 and 6 to dental health and quality of life of children according to the modified EGOHID criteria.

Materials and Methods. To this purpose, by use of Google form we conducted questionnaires of 257 parents of children aged 3-6. Subjective assessment of dental health included questions about the frequency of brushing, assessing the condition of teeth and gums, oral care products and items and checking the effectiveness of brushing, diet, especially the use of sweets, and whether parents pay attention in general on the appearance of temporary teeth in children, the frequency of visits to general practitioners, including dentists.

Results and Discussion. We found that more than half (57.26 \%) of parents go to the dentist for the first time for treatment of their children, and for preventive examination - only $25.67 \%$. Oral care with the appearance of the first tooth started $56.62 \%$ of parents, after a year $-37.43 \%$ of respondents, from two years - $16.05 \%$. Only half of the respondents (49.36 \%) brush their children's teeth twice a day, the rest only once. It is gratifying that the vast majority of parents $(67.67 \%)$ still brush their children's teeth themselves, but only $3.22 \%$ of respondents check the effectiveness of brushing their teeth with a special solution. Regarding the composition of toothpaste, only $47.93 \%$ of parents of children indicate the use of calcium-containing toothpaste, the rest do not know the composition of the toothpaste. $99.14 \%$ of parents surveyed do not use additional dental tools. $55.52 \%$ of respondents indicate that children consume sweets once a day, a third (respectively $30.84 \%$ ) - several times a day, the rest - less often. $46.23 \%$ of respondents believe that you need to see a dentist only in case of acute pain. $65.76 \%$ of parents indicated the need for treatment of temporary teeth, the rest - consider it optional. TV (41.89\%) and the surrounded people (32.45\%) most often influence parents' choice of oral hygiene products.

Conclusions. As a result of a subjective survey, we found insufficient attention of parents to the state of children's dental health, poor oral care and nutritional deficiencies.

Key words: dental health; caries; EGOHID.

\section{СПИСОК ЛІТЕРАТУРИ}

1. Безвушко Е. В. Рівень санітарно-гігієнічних знань у дітей дошкільного та шкільного віку м. Львова / Е. В. Безвушко, Н. Л. Чухрай, І. С. Дубецька // Новини стоматології. - 2007. - № 4 (53). - С. 33-36.

2. Бирина О. С. Теоретическое обоснование применения комплексной программы профилактики основных стоматологических заболеваний / О. С. Бирина // Пермский медицинский журнал. 2012. - № 6. - С. 128-136.
3. Клітинська О. В. Ранжування уражень карієсом зубів у дітей при ретроспективному аналізі первинної медичної документації / О.В.Клітинська, А. А. Васько // Україна. Здоров’я нації. - 2016. - № 3 (39). - C. 45-48.

4. Global epidemiology of dental caries and severe periodontitis - a comprehensive review / J. E. Frencken, P. Sharma, L. Stenhouse [et al.] // J. Clin. Periodontol. 2017. - Vol. 44 (18). - C. 94-105. 
5. Kassebaum N. J. Global, regional, and national prevalence, incidence, and disability-adjusted life years for oral conditions for 195 Countries, 1990-2015: a systematic analysis for the global burden of diseases, injuries, and risk factors / N. J. Kassebaum, AG.C. Smith,

\section{REFERENCES}

1. Bezvushko, E.V., Chukhrai, N.L., \& Dubetska, I.S (2007). Riven sanitarno-hihiienichnykh znan u ditei doshkilnoho ta shkilnoho viku m. Lvova [Level of sanitary and hygienic knowledge in children of preschool and school age in Lviv]. Novyny stomatolohii - Dentistry News, 4 (53), 33-36 [in Ukrainian].

2. Birina, O.S. (2012). Teoreticheskoe obosnovanie primeneniya kompleksnoy programmyi profilaktiki osnovnyih stomatologicheskih zabolevaniy [Theoretical substantiation of application of the complex program of prevention of the main stomatologic diseases]. Permskiy meditsinskiy zhurnal - Perm Medical Journal, 6, 128-136 [in Russian].

3. Klitynska, O.V., \& Vasko, A.A. (2016). Ranzhuvannia urazhen kariiesom zubiv u ditei pry retrospektyvnomu analizi pervynnoi medychnoi dokumentatsii [Ranking of dental caries in children with a retrospective analysis
E. Bernabé // J. Dent. Res. - 2017. - № 96 (4). - C. 361-363. 6. World Health Organization. Global consultation on public health intervention against early childhood caries. - Bangkok, Thailand, 2016. - 45 p.

of primary medical records]. Ukraina. Zdorovia natsii - Ukraine. Health of the Nation, 3 (39), 45-48 [in Ukrainian].

4. Frencken, J.E., Sharma, P., Stenhouse, L., Green, D., Laverty, D., \& Dietrich, T. (2017). Global epidemiology of dental caries and severe periodontitis - a comprehensive review. J. Clin. Periodontal., 44 (18), 94-105.

5. Kassebaum, N.J., Smith, A.G.C., \& Bernabé, E. (2017). Global, regional, and national prevalence, incidence, and disability-adjusted life years for oral conditions for 195 Countries, 1990-2015: a systematic analysis for the global burden of diseases, injuries, and risk factors. $J$. Dent. Res., 96 (4), 361-363.

6. World Health Organization (2016). Global consultation on public health intervention against early childhood caries. Bangkok, Thailand. 